\section{An Alumas:}

on

RICHARD BRIGHT: THE MAN AND THE PHYSICIAN.

\section{GIVE aT GUY'S FOAPTTAL ON THE OCCAGION OF THE Centenary Cemebration* \\ BY}

W. S. THAYER, M.D., F.R.C.P.IRE.,

gMERITUS PROFESSOR OF MEDICINE, JOHNS HOPKINS UNIVERSITY, MATTMORE.

"For my own part I am very fond of seeing . . ." R. BRIGHT: Letter to his father, 26th June, 1813.

To be asked to speak to you on Bright, on this occasion, at the scene of his activities and unfler these auspices, is an homorar of which I am deeply sensible, so sensible that I shall not attempt to thank you.

\section{Eariy Ltre and Traveis.}

Richard Bright, the third son of Richard Bright, a well-to-do and influential banker of Ham Green, Somerset, was born at Queen Square, in Bristol, on September 28th, 1789, seven and a half years after Laennec. At the private : ochaol of Br. Wstlin, near Bristel, he was the companion of Fenry, afterwards Sir Fenry, Folland, who speaks of him as his " most intimate friend." Later Bright studied at Txeter under the private tuition of Dr. Carpenter, and in 1808 matriculated at Edinburgh, where, during his first year, he devoted himself largely to the lectures of Dugald Stewart, on moral philosephy and pelitical economy, to those of Playfair, on natural philosoplry, and of Lestie, on mathematies. The following year he applied to the stady of anatomy, working under Hope, Monroe, and Duncan.

In the summer of 1810 Bright and his friend Holland accompanied Sir George Steuart Mackenzie on an expedition to Iceland. Mackenzie speaks cordially of his young comparions and of Bright's contributions to the study of the botany and zoology of Iceland, which are puiblished in the history of the expedition; he shall, he says, "ever retain a grateful pemembrance of the cheerful and ready exertion he alwars displayed and the unfailing good humour with which he submitted to the cross accidents which sometimes befell us."

The journal of the excursion tells of a number of interesting experiences, one of which, the rather perilous ascent of the Snaefell Jokul, is really well told by Bright, who oontributed several excellent drawings to the illustations. The journey was not without event; they were mearly shipwrecked on their homeward voyage.

On his return Bright attended at Guy's Hospital in London, where he studied under $W$. Babington, Currie, Astley Cooper, the two Clines, and Traver's. From association with Babington he gained an interest in geology, and, in the fall of 1811, he contributed to the Geological Society a brief statement on the strata in the neighbourhood of Bristol.

Returning to Edinburgh in 1812, he worked under Gregory, at the same time studying geology and natural history under Jameson, and took his degree of M.D. on September 13th, 1813, with a dissertation "De erisipelato contagioso," on the title-page of which is the happily chosen motto: " Foenum habet in cornu, longe fuge. . . ." (Hor., Sut., Iib. 1, Sat. iv.): "He has hay on his horn; give him a wide berth!"

$\mathrm{He}$ was a member and president of the Royal Medical Societr, a students' organization, to which he contributed a dissertation on "Gangrene"; and of the Speculative Society, where he was brought inte association with companions interested in general Titerature and the law.

After two terms at Peterhouse in Cambridge he returned to London in the fall of 1813, becoming a pupil of Bateman at the Public Dispensary. In the summer of

* The centenary oelebrateo was that of the publication of the first volume of Bright's Reports of Mellical Cases. Professor Thayor's address, as hare printed, was deliveres on July 8th. The complate text will be published in the forthcoming Bright Centenary Number of Guy's Aospital Reports, where it will be accompanied by a full bibliography.
1814 he passed some months on the continent in Holland, Belgium, and Germany, where, at Berlin, he studied under Forn and Hufeland, "besides profiting by the acquaintance of other eminent men of science," notably Klaproth, Rudolphi, and Heim. Passing through Dresden, he spent the winter of 1814-15 in Vienna, studying with Hildenbrandt, and in the ophthalmological clinics of Rust and Beer. He appears to have had a pleasant acquaintanoe with many interesting men, especially Jacquin the botanist, Prochaska, and the elder Frank. Napoleon at Elba, the Allies in Congress at Vienna, were dining and dancing and struggling with the problems of peace. Bright gives an interesting account of the social pomp and ceremony associated with the occasion, and a not unentertaining desoription of some of the leading figures as they passed before him at an evening function. His account of a visit to the little prince at Schoenbrunn is rather touchïng.

The spring he spent in travel through lower Hungary, arriving in Brussels again two weeks after the battle of Waterloo; here his experiences in the military hospitals are said to have been valuable.

These travels he described in a handsome quarto volume, illustrated with excellent sketches by his own pencil. The book is not written in a sparkling fashion. It cannot be said to betray a lively sense of humour, but the accuracy and catholicity of his observations-geological, botanical, agricultural, economical, ethnological, social, educational, political-his scrupulous objectivity, and the carefal detail of his descriptions are very striking. It is clearly the work of a keen observer and a serious student. But the book shows something more. It gives the pioture of a young man of six-and-twemty capable of observing and describing the strange customs and life of a people new to him with measure and charity and anderstanding, seeking out and recognizing that which is good, and never allowing a hasty or an unkind eriticism to escape his pen. Such measure and such understanding are not common at six-and-twenty; they are characteristic of Bright throughout his career.

Returning to Fngland he read before the Geological Society a short note on some interesting volcanic formations in Hungary. In 1816 he was admitted licentiate of the Royal College of Physicians, and shortly thereafter was made assistant physician to the London Fever Hospital, where he himself arequired a severe fever of which he nearty died. In 1818 he again visited the continent, spending several months in Germany, the Tyrol, Italy, Switzerland, and France.

In 1820 he was made assistant physician at Guy's, and resigned his position at the Fever Hospital. In 1821 be was elected Fellow of the Royal Society. Soon after obtaining his hospital appointment Bright began to teach, lecturing on botany in its relation to materia medica from 1822 to 1825 . In 1823 he gave his first clinical lectures, and, in the following year, he was made full physician to Guy's Hospital, sharing with Cholmeley the course on theory and practice. ${ }^{*}$ For many years afiterwards be shared these lectures with Addison.

There is an amusing reference to Bright in a somewhat facetious note in a contemporary medical journal signed $\Delta . E .1$. In connexion with the programme of lectures for the term the destructive chronicler says we may "... almost fancy ourselves in the seventeenth century... . In the Practice of Medicine, disorders of the intellect will be reflected by Dr. Bright, of whom it is not too much to say with the poet,

$$
\text { "Natura lo fece, è poi ruppe la stampa'!"† }
$$

It was a stimulating period in medicine. After long centuries of more or less blind worship of tradition, of authority and of doctrine, during which that which was most certain in medicine was the rather conjectural art of prognosis, physicians were beginning to use and trust

* How sincerety Bright appreciated this appointment is manifested by his remarks at the anniversary dinner at Guy's Hosprtal in 1825. "The Chairman next toasted 'The Physicians of Guy's Hospital.' Dr. Bright rose. He said somebody had told him he must return thanks. "Gentlemen, said the Doctor with great energy, 'I will return thanks: to hold the situation of physician to Guy's Hospital is to be placed at the pinnacle of the profession. I am thankful-I am proud of a situation which has produced a Saunders; a Babington, and a
t Nature shaped him, and then broke the mould. 
their senses, to investigate and explore for themselves. Morgagni had accumulated and placed side by side in massive volumes the brief clinical story and the description of the anatomical changes in the organs in hundreds of instances of mortal disease or injury. Auenbruggerneglected for fifty years and rediscovered by Corvisart-had demonstrated how, with our fingers, we may determine the outlines and physical characteristics of the contents of the thorax. Bichat, in the few short years of his vigorous activity, had laid the foundations of pathological anatomy; and when Bichat fell, and Bayle, so full of promise, dropped by the way, the genius of Laennec had revealed methods of study. which permitted the recognition and fuller comprehension, during life, of many processes which, unrecognized; led to those fatal changes with which they had become familiar in the dead. Freed from the bonds of dogma men were using their senses and their reason in the study of disease.

Bright was fired by the spirit of the times. From the day he entered Guy's Hospital he devoted himself wholeheartedly to the study of morbid phenomena, year after year spending as much as six hours a day at the bedside and in the necropsy room. Occasional notes of cases demonstrated during his visits show how. carefully, even at this early period; he observed and noted the recondite; an example is a good description of what obviously was an instanee of syringomyelia. For seven years he published little or nothing, but never were seven years better spent. On August 13th; 1826; Laennec died; leaving the legacy of the great work with the immortal descriptions of tuberculosis, of pneumonia, of bronchiectasis, of emphysema, the work which laid the foundations of modern physical diagnosis of diseases of the chest. Bright took up the torch, and, a twelvemonth later, one hundred years ago, rendered a noble account of his stewardship at Guy's in the form of the first beautiful quarto volume of his Reports of Medical Cases. This remarkable collection of observations, clinical and anatomical, was made for the most part during the three years of his service as full physician. Bright points out scrupulously that among the comments and inferences there are some for which he " must bear the responsibility alone. Such are the statements and conjectures regarding the dependence of a peculiar class of dropsies on disease and irritation of the kidneys. Such are some observations on the peculiar changes in the structure of the liver; . . . and such are the hints thrown out on the influence of the peculiar state of the mesenteric absorbents on the symptorns of phthisis."

\section{The Recognition of Bright's Disease.}

He first discusses a group of "Cases illustrative of some of the appearances observable on the examination of diseases terminating in dropsical effusion "-notably “... appearances to which I think little attention has hitherto been paid . . . evidences of organic change which occasionally present themselves in the structure of the kidney; and which, whether they are to be considered as the cause of dropsical effusion or as the consequence of some other disease, cannot be unimportant." With these conditions he has "often found the dropsy connected with the secretion of albuminous urine, more or less coagulable on the application of heat. . . . I have never yet examined the body of a patient dying with dropsy attended with ccagulable urine, in whom some obvious derangement was not discovered in the kidneys."

The observation that dropsy was sometimes associated with hardening of the kidneys was not new. Aëtius in the fifth century and William Salicet in the thirteenth had nirntioned it. In like manner the association of albuminous urine with certain dropsies had been pointed out iit 1770 by Cotugno, who quite misinterpreted its significance, and notably by Cruikshank, by Darwin, and later by Wells and by Blackall, each of whom noted the presence of renal disease in individual instances; neither, however, recognizing its full significance.

Such was the situation when Bright began his studies. In three years of hospital experience he had grasped the situation and was able to make the statements which have been quoted. Bright continues cautiously and judiciously:
"Whether the morbid structure, by which my attention was first directed to this subject, is to be considered as having in its incipient state given rise to an alteration in the secreting power, or whether the organic change be the consequence of a long continued morbid action, may admit of doubt; the more probable solution appears to be, that the altered action of the kidney is the result of the various hurtful causes influencing it through the medium of the stomach and the skin, thus deranging the healthy balance of -the circulation, or - producing a decidedly inflammatory state of the kidney itself :-that when this continues long, the structure of the kidney becomes permanently changed, either in accordance with, and in furtherance of, that morbid action; or.by a deposit which is the consequence of the morbid action. ...

"Where anasarca has come on from exposure to cold, or from some accidental excess, I have in general found the urine to be coagulable by heat. .

"During some part of the progress of these cases of anasarca, I have in almost all instances found a great tendency to throw off the red particles of the blood by the kidneys; betrayed by various degrees of haematuria from the simple dingy colour of the urine, which is usually recognized; or the slight brown deposit; -to the completely bloody urine. ..."

Coagulable urine he has observed not only in these cases of sudden anasarcous swelling but also

" in persons long the subjects of anasarca, recurring again and again, worn out and cachectic in their whole frame and appearance, and usually persons addicted to an irregular life and to the use of spirituous liquors. ... In all the cases in which $I$ have observed the albuminous urine, it has appeared to me that the kidney las itself acted a more important part, and has been more deranged both functionally and organically than has generally been imagined. In the latter class of cases I have always found the kidney decidedly disorganized. In the former, when very recent, I have found the kidney gorged with blood. And in mixed cases, where the attack was recent, although apparently the foundation has been laid for it in a course of intemperance, I have found the kidney likewise disorganized."

It is nearly twelve years since he first observed the altered structure of the kidney in a patient who had died dropsical; and he still has the slight drawing made at the time. Then follows an excellent description of four-andtwenty instances of dropsy with albuminous urine, seventeen of which came to necropsy and showed renal disease. On the whole these four-and-twenty cases represent the ordinary pictures of acute and chronic renal disease-acute haemorrhagic nephritis, subacute and chronic hydropigenic nephritis or nephrosis, slow chronic nephritis with or without striking general arterial change.

In his summary Bright distinguishes three stages of a disease which he inclines to believe to be progressive. In the first stage the changes consist largely in the cloudiness and mottling of the renal substance; in the second, granulation has begun; in the third, the kidney is sclerotic and contracted with an irregular, nodular surface. It is rather odd, as Rayer points out, that he pays so little attention to acute haemorrhagic nephritis, of which he described at least one clear instance.

From a clinical standpoint Bright notes the frequency of complicating serositis-pleurisy, pericarditis, peritonitis - and comments on the insidious origin of these complications. He tells of the frequency of "apoplexy" (coma) and "epilepsy." In four of the subjects the heart was found to be hypertrophied. He discusses the chemical reports of Bostock, which show that the specific gravity of the urine, varying from 1006 to 1032 , is usually lower than normal, and he comments especially on the evidence of diminution in the quantity of urea in the urine and the presence of an urea-like substance in the blood serum in advanced disease.

With regard to treatment he is rather conservative; especially is he sceptical as to the wisdom of the employment of mercury.

The plates are of great beauty, and record that which Bright saw in such fashion as to make the subject clear to readers of that day and this.

Such are the simple and soberly written pages in which Bright laid the foundations of our present knowledge of nephritis. Bright's work was widely discussed at home and abroad, criticized by some who spoke arbitrarily but with authority. The essentials were soon confirmed by the students. 
Before going on with the story of his life, let us pass rapidly over his later publications on this subject. In his second volume of Reports, published in 1831, he protests (p. $x)$ against a misunderstanding on the part of some of his contemporaries who had assumed that he believed that coagulable urine was observed only in the presence of organic renal disease, and, quoting the careful statements made in his original publication, he ends with the words: ". . I I am inclined to believe that the functional derange ment of the organ may sometimes precede a structural change for a period of many weeks and many months, and that the kidneys of a patient thus affected, who has been cut off early by some disease, may afford very little evidence of diseased structure."

$\mathrm{He}$ repeatedly mentions pial (arachnoid) oedema in individuals dead of uraemia, and points out that the same cerebral manifestations, convulsions and coma, which, in suppression of urine, precede death, are met with in diseases which " pervert the qualities of the secretion. ... That such derangements in the natural secretions and excretions should greatly influence the brain, ceases to be a matter of astonishment, when we find that the blood of those who have albuminous urine is often highly impregnated with urea, while it is deficient in its due proportion of albumen. . . ." "Effusion of blood or serum into the brain is one of the great causes of danger in renal disease."

Experience has confirmed him in taking a rather serious view of chronic albuminuria (p. 449). There are long remissions but frequent relapses. He speaks of the grave prognostic influence of functional or organic disease of the kidney as a complication of acute disease or severe injury. The urine should always be examined before contemplated operations; but one examination is not enough, for sometimes when the disease is advanced, "a simple serous secretion passes, with scarcely any albumen;... and I early perceived that there was no direct ratio between the degree of disease and the quantity of albumen. ... Perhaps, in some doubtful cases, an examination of the serum of the blood to ascertain its condition both as regards the presence of urea and the proportion of albumen might be useful."

In his Goulstonian lectures, after discussing the character of the normal urinary secretion, the variations of the specific gravity, and the methods of testing for albumen, especially the use of heat and nitric acid, he refers to the confusion which may be caused by the precipitation of phosphates by heat or of urates in testing with nitric acid. As renal disease goes on, the urine loses the properties which it derives from the presence of urea, while urea becomes demonstrable in the circulating blood. Whatever becomes of the urea in the blood, "it is plain that what appears to be the great office of the kidney-the depuration of the blood-does not take place." Anasarca itself does not always accompany albuminous urine, and it should be remembered that anasarca may occur without albuminous urine. He reviews the arguments which justify his assumption that renal disease is at the root of the clinical symptoms which he has described, and he refers again to the common complications of the disease.

In 1836 he gives a more or less complete summary of his work and tells the story of the disease in a clear and concise manner. $\mathrm{He}$ emphasizes the frequency of the condition and discusses with almost legal caution those which ho regards as its commoner causes-" scarlatina or some other acute disease "-intemperance, exposure to cold. In his description of the clinical symptoms, among which he notes the fullness and hardness of the pulse, and his discussions, anatomical, physiological, and pathological, he has done about as much as one could do without the microscope and the ophthalmoscope.

Following this is a tabular review of the morbid affections in one hundred patients with albuminous urine in which he treats especially of the complications of renal discase. In the discussion of the cause of the common left ventricular hypertrophy, he asks whether it may be due " to an affection of the minute and capillary circulation so that greater action is necessary to force the blood through the distant subdivisions of the vascular system."

Four years later he again protests against the assumption by some witers that he regards albuminuria as necessarily evidence of a progressive and fatal disease, and relates a series of instances of acute, many of scarlatinal, nephritis. In 1842 Bright published a brief note on some microscopical studies with Toynbee, which led them to believe that the essential element in the disease was the glomerular change.

This ends the contributions that Bright made to the study of renal disease in his own name, although, as we shall see, valuable studies wcre made later under his guidance and direction. In a little less than ten years he had brought into medicine a remarkably clear clinical and pathological conception of those forms of renal disease which since then have come to be associated with his name. Bright's contribution was not a mere recognition of the association of clinical symptoms with anatomical change; studies had been made not only of the urine but of the blood serum and body fluids, and he had been led into various speculations of a physiological nature. He was one of the first to introduce methods of quantitative chemical study into routine medical practice.

One may say, as has been said, that the world was ripe for his discoveries. Perhaps it was. The world is always ripe for men such as Bright.

Other Clinical Stedies.

But Bright did much more than discover the relation between albuminuria, dropsy, and renal disease. In his first quarto he took up the study of dropsical effusion connected with disease of the liver, presenting with remarkable clearness and precision a series of cases of hepatic cirrhosis, of which he treats in his later observations on jaundice and on abdominal tumours. He records two cases of cardiac infarction with intraventricular thrombi, one associated with sudden death; their nature he does not recognize. He describes the chronic peritonitis occurring in ascites of long duration, which he believes to be due "to a slow inflammation kept up by the unnatural stimulus of the fluid."

He relates the histories of a series of cases of bronchitis with several necropsies; one wonders whether Laennec would not have regarded two of these as instances of emphysema. Sections are devoted to the termination of pneumonia in suppuration and gangrene, and to phthisis pulmonals; they are accompanied by beautiful illustrations. "Obstruction of the mesenteric glands by tuberculous disease" he regards as an important cause of emaciation, and he describes and pictures the caseous (" engorged") lacteals making their way to such glands.

There are admirable descriptions and plates of the intestinal lesions in typhoid fever, "changes never suspected to be as general until brought into view by the French physicians."

During the four years between the appearance of the first and sccond parts of the Reports, the greater part of Bright's time appears to have been given to his hospital studies and to his teaching. He played an active part in the regeneration of the Guy's Physical Society, of which he was President for the year 1829-30. The only other publications appear to have been the outlines of his lectures for 1827 and a brief report of an instance of unusually profuse sweating.

In the second quarto of his Reports, devoted to diseases of the brain and meninges, Bright records over three hundred cases, for the most part with necropsy, and with comment which is often strikingly acute and discriminating.

$\mathrm{He}$ describes and pictures suppurative meningitis and abscesses of the brain secondary to diseases of the middle ear and of the accessory sinuses and to erysipelas. In his account of "acute hydrocephalus" he recognizes its association with tuberculosis in brain, meninges, and elsewhere, but he concludes that ". . . it would seem that the Hydrocephalus is rather the result of the constitutional tendency than of the tubercles, though these morbid deposits are probably often the exciting cause." How close he came to that which Papavoine was recognizing at the same moment, which Gerhard set forth so clearly two years later! He regards headaches as usually dependent on cerebral congestion.

$\mathrm{He}$ describes sclerosis of the medullary substance of the brain in an instance of familial spastic diplegia, and of the cord which was " remarkably firm throughout, almost 
like cartilage," in a case of pontine tumour, ascribing the spasticity to these changes. He mentions the frequency of venous thrombesis under the influence of debilitating causes. He calls attention to tho "leaden gray colour" of the viscera and later to the pigmentation (" colour of black lead") of the brain in patients who had evidently died of pernicious malaria.

He recounts many instances of Jacksonian epilepsy. But, more than this, he recognizes the significance of the syndrome and describes it repeatedly with great clearness.

Among the many recorded instances of haemorrhage, softening and pressure by growths, there are interesting and acute observations on cerebral localization. Later, he reported two instances of tumours situated at or about the cerebellar pontine angle; one apparently cerebellar in origin. Of these he says: "There has been so great a resemblance in the syniptoms, as to confirm the feeling which I always entertain and wish to enforce-that in disease, as in other matter's, thero is a fixed relation, which it is possible we may discover between cause and effect. ...."

In connexion with two instances of amnestic aphasia with central lesions he observes: "When we review the cases which I have thus thrown together, I trust that, in one point, the connexion between them will be obvious; in as much as they all serve, more or less to establish and keep up our conviction, that the symptoms which arise in cerebral and spinal disease are actually the results and therefore the fair representatives, of the lesions which the different portions of the nervous system have suffered." Defects of speech he has observed are often associated with lesions of the posterior part of the corpus striatum. He recognizes the frequent sclerosis of the arteries at the base of the brain and notes that the common seat of haemorrhage " is undoubtedly a little to the outside of the corpus striatum in either hemisphere, just at that part where many large vessels may be traced coming from the trunks in the Fossa Sylvii, and pervading the brain."

In connexion with the formation of bullae in several cases of paraplegia, it occurs to him that ". . . this connexion between interrupted nervous action and the formation of Bullae, might hereafter be found to throw light on the nature of that most singular disease Herpes Zoster, which, from the peculiar pain with which it is associated, as well as its striking confinement to one side of the body, seems to be connected with some peculiar condition, perhaps the distention, of the sentient nerves."

In a necropsy on a negro he noted that the "skull was thick and heavy in a remarkable degreo"-a racial characteristic familiar to those of us who live in the south.

Ho describes, I believe for the first time in literature, a characteristic instanco of that which later was known as Addison's diseaso with caseated adrenals.

In an instance of diabetes he notes the extreme scirrhous degeneration of the pancreas. He describes an obvious example of what later came to be known as "Adams-Stokes syndrome" with slow pulse and sudden death.

Conservative in therapeutics, he makes an observation in connexion with the treatment of chorea which, in a broader sense, might well be meditated upon by the profession of to-day: "I have oecasionally known instances in which arsenic has been successfully-administered; but I object to this remedy where others less hazardous will act as well."

The association of rheumatic fever, chorea, and cardiac disease is discusséd often and interestingly. In a later article, he refers to pericarditis as an occasional cause of chorea.

Convulsive phenomena are discussed at some length.

The clinical account of tetanus is remarkable; that of hydrophobia is masterly. How striking is the following observation :

"As regards the symptoms of the confirmed disease they bespeak the highest state of nervous irritability; and affecting, as they do, almost exclusively in the first instance, the functions of respiration and deglutition, and in some degree the circulation of respiration and deglutition, and in some degree the circulation,
they seem to be immediately dependent upon some morbid action excited in the nerves of organic life, or that particular set of nerves which has been sc beautifully illustrated by-Mr. Charles Fell as connected with the respiratory apparatus :-and looking to tho large proportion of those who are bitten, yet who escape entirely from the disease, it might perhaps arise as a legitimate question, whether it is not one of the conditions necessary to the production of the disease, that some nervous fibre immediately connected with that system should have been wounded."

The second quarto appeared but seven years after Bright had acquired the opportunities offered by wards of his own. The quiet, modest young man who had schooled himself from the beginning to observe, to note, to picture, to record all that which he could grasp of Nature and her works, had been true to his promise; in his medical inquiries he had shown the same keen, sure powers of obscrvation, the same industry, the same mental poise, the same sound, sane judgement that he had manifested in his earliest writings. At the age of 42 he had seen and comprehended and recorded and illustrated his experiences in communications which stand out among the great contributions to niedicine.

\section{Medical Education and Clinical Study.}

In 1832, following the publication of his second quarto, Bright was promoted from Licentiate to the full Fellowship in the Royal College of Physicians. He had become distinguished among his colleagues and loved by his pupils.

The introduction to his course of lectures at Guy's, published in 1832 at the request of his students, contains passages which can scarcely be passed over. $\mathrm{He}$ insists on a "sound classical and mathematical foundation on which to build," on the study of the fundamental sciences as the " corner-stone" of the " edifice," but ho warns the student to remember that " the practice of medicine is the most important part of the medical practitioner's education." and urges the necessity of obtaining a " connected knowledge of those diseases which . . . will be the chief objects of his practice, the daily betrayers of his ignorance, or the touch stones of his skill."

In Bright's days also there were those who failed to comprehend until too late, that long-continued, often wearisome, daily experience in clinical observation is vital for the development of the true physician.

"We have all of us senses, it is true," but " . . . without much experience our senses remain most imperfect. compared with the exquisite perfection to which they arè brought by practice. . . ." On the accuracy of his observation all the deductions of the physician must depend.

"By the eye you will learn much; many diseases have the most distinct physiognomy. The sunk and shrivelled features derived from the long-continued disease of the abdominal viscera; the white and bloated countenance often attendant on changes in functions or structure of the kidneys;the sallow and puffy cheeks, of the liver" (a surprising picture if taken literally!) " diseased from habitual intemperance;-the squalid and mottled complexion of the cachexia dependent upon the united effects of the mercury, and siphilis" (sic); "the pallid face of haemorrhage; - the waxen hue of amenorrhoea;-the dingy whiteness of malignant disease; - the vacant lassitude of fever; - the purple cheek of pneumonia; - the bright flush of phthisis;-the contracted features and corrugated brow of tetanus. . .." We can forgive the liver's "puffy cheeks" in one who could have written "the vacant lassitude of fever." $\mathrm{He}$ refers to the perfection to which the sense of touch is elevated in the blind, and says : " $\because$ to a certain degree wo may all acquire such accuracy of touch, and it is our duty to do it." The necessity of continued observation of common clinical phenomena is emphasized, especially regular and repeated visits to those suffering from acuto disease.

In the same year Bright described, for the first time in medical literature, the passage of large quantities of neutral fat in the stools of individuals suffering from disease of the head of the pancreas and duodenum, and in his admirable discussions here, and later, he is inclined to regard the phenomenon as due to "obstruction" in the pancreas.

Bright's father-in-law, William Babington, died in 1833, and the first Goulstonian lecture was preceded by a warm tribute to his friend and teacher. The qualities which he praises in his master are curiously like those which his friends discovered in him. In these lectures on the functions and diseases of the abdomen, lectures which aro full 
of wise observation and comment, he refers briefly but very clearly to an instance of generalized scleroderma.

A little further on he describes the character and significance of peritoneal friction, and the " dough-like sensation" or "hard, knotty feel" in the abdomen, the seat of chronic, proliferative peritonitis, of which malady, two years later, he gives the first clear account. In the course of this article he throws out the suggestion that if, in serous effusions, some method could be devised of inciting inflammatory action short of producing grave adhesions, it might have a curative effect on the effusion.

In 1836, and again in 1839, Bright was a censor of the Royal College of Physicians. In the former year appeared the first volume of Guy's Hospital Reports. How active Bright was at this time is indicated by the eight communications from his pen. The first of these, on the treatment of fever, begins with the words: "It is a duty incumbent upon the physician who has ventured at any time to lay before the profession his ideas of disease and its treatment, to review from time to time his published opinions that he may see how far subsequent experience has borne out, or modified, his former impressions: and if he detect any material alteration in his mode of viewing disease, more particularly as respects the practice he has found beneficial, it is right that he should take an opportunity to make it known." This statement gives the opportunity to an anonymous and atrabilious scribe for the assertion that "... Dr. Bright had for many years abandoned a practice which he had previously recommended for its excellence to the profession, without ever hinting to them until this very day, that that practice was materially calculated to keep up the disease which he originally designed it to lessen."

Whatever Bright's inward reaction to attacks of this sort may have been, he appears to have followed the wise advice of the Rev. Cotton Mather: "Sile, et funestam dedisti Plagam."**

Beside the description of a case of tetanus and studies of cerebral and renal disease already referred to, there follows a well described and little known observation of diaphragmatic hernia and observations on jaundice in which acute yellow atrophy of the liver is described for the first time, and an interesting note on the manner of spread of cancer in the liver. In one note he comments on the frequency. With which the swollen liver of passive congestion is evidence of an overlooked cardiac disease. At another point he refers to the frequency of rigors in cholelithiasis.

Bright had become one of the leaders of the profession. His observations on renal disease were the subject of active discussion the world over. In the following year he published the first of a series of articles on abdominal disease, especially tumours, which, later, were collected into a volume and edited under the auspices of the New Sydenham Society by Barlow. These communications are a mine of raluable observation and sane and acute comment. His observations on hydatid cysts, especially those relating to the development of the daughter cysts, are quite original. His discussion of ovarian tumours, of diseases of the spleen, of the kidneys, and of the liver are full of suggestive, interesting, and original observations. He recognizes the frequency of anaemia and the haemorrhagic tendency in connexion with disease of the spleen, and he describes clearly an instance of that which later became known as Hodgkin's disease. He emphasizes the association of cirrhosis of the liver with alcoholic habits.

In 1837 he delivered the Lumleian lectures on disorders of the brain which, apparently, remained unpublished, and in the same year he was made Physician Extraordinary to the Queen.

Some Batts and Owls.

In 1839 appeared the first volume of the Elements of the Practice of Medicine by Bright and his associate Thomas Addison; the second volume was never published. Written as a book of reference for students, it is notable for the clearness and conciseness of its excollent clinical pictures, and its accurate anatomical descriptions. The

* Mather, Cotton: Manuductio ad Ministerium. Directions for a Candidat of the Ministry, etc, 8vo, Boston, printed for Thomas Hancock
and $\mathrm{Co} ., 1726,142$. authors, for example, recognize that faecal abscess " in the right iliac region, arises in a large majority of instances from disease set up in the appendix caeci." "The description of this process, as Hale-White has pointed out, is far in advance of anything of its time; it can scarcely be excelled to-day.

But excellent though the work was, "the Batts and the Owls" muttered, and to a leading journal of medicine one of the former contributed a dismal and depreciatory review of the volume. The critic who airs his familiarity. with, and betrays his incomprehension of, the French literature asserts solemnly that " these 'Elements' rank much, much below mediocrity." The review ends with an attack on the existing method of distributing hospital appointments. "So long as it exists, laziness will be the distinguishing characteristic of those who hold them." The rich who buy their positions will think of naught but striking bargains; the enthusiasm of the poor man "will be crushed, 'ere it can lead to action, and his spirit soured as he looks on the disgraceful inefficiency of

\section{- ... those baleful, unclean birds,}

Those lazy owls, who (perched near Fortune's top)

Sit watchful with their heavy wings

To cuff down new-fledged virtues that would rise

To nobler heights, and make the grove harmonious!"'

This is indeed a sad picture!

And there were the "Owls" as well as the "Batts." In 1839 one Richard Bright of 25, Ely Street, Holborn, M.R.C.S. and "Author of a Popular Treatise on the Diseases of Females; entitled Every Woman's Book; or Female's Physician," published a small octavo volume on the treatment of dropsy. After a somewhat preposterous discussion of "dropsy" as a disease, there follows a rather hazy description of the author's successful treatment of the malady, and a series of illustrative cases. It is obviously the work of a member of the profession whose eye was fixed upon the main chance. At the conclusion, the writer devotes a page to the defence of his medical character and standing, which have been attacked by evil-minded men. $\mathrm{He}$ has, it appears, attended lectures for nearly six years at Guy's, and acquired his physician's diploma in 1837. In proof of his good standing, he adduces a series of carefully worded but pleasant testimonials from Sir Astley Cooper, Sir Benjamin Brodie, Addison; Gordon, Bransby Cooper, Robert Keate, and Charles Aston Key. But the author appears to have suffered from doubts and premonitions; all his testimonials are dated 1837, two years before the publication of his book.

The "Batts" may annoy, but profit little by their feverish flutterings; the "Owls" are wiser. One may fancy that Richard of Holborn may have drawn from the public a fair measure of the balm that he sought. As he may have hoped, his great work has for nearly fifty years been ascribed, in one important medical bibliography at least, to another Richard Bright whose name does not appear in the book.

But the "Batts" and the "Ouls" failed to disturb Bright, who seems to have gone his way unperturbed, notwithstanding what old Mather called " the unregardable allatrations " of his adversaries.*

\section{Retirement from GuY's.}

Bright had enjoyed the privilege of his position at Guy's for nearly twenty years. He had made the most of his opportunities, and had observed keenly and recorded accurately and conscientiously that which he had obseívéd. That "chastened power" of generalization, and the "cautious habit of reasoning upon facts" which he had urged upon his students had enabled him greatly to enrich medical literature. In 1843 he was seriously ill, and at the early age of four-and-fifty he retired from the hospital positions of which he had made such good use. But the last use that he made of his service at Guy's was notable. In the spring of 1842 he obtained the permission of the

* Bright's equanimity appears to have been remarkable. One Holloway an aikertising quack, announced in print that Bright had recommended his treatment, and the lancet, scandalized, demanded a denial. Bright ignored it ail, telling his friends that the advertisement was beneath his notice. Bright was probably wise, for at Holloway's elbow stood none other than our old friend Richard of Holborn. 
authorities to set aside for a period of six months two clinical wards of 42 beds in all, with an intermediate room for consultations and the recording of histories, and an adjoining and comminicating laboratory for the intensive study of renal disease. Bright refers to the experiment as the first made in England " to turn the ample resources of an hospital to the investigation of a particular disease. ...

The results of these studies were published in the Hospital Reports for 1843 in the names of his chief associates, Barlow and Rees, with a short prefatory note by Bright. The communication, with detailed clinical histories, thorough and accurately recorded physical examinations, careful necropsies, chemical studies of the urine, blood, and body fluids, is a fitting climax to Bright's labours on renal disease, and marks in striking manner the progress which clinical medicine had made in his day. But what is yet more striking and quite characteristic is that these studies, planned, inspired, and directed by Bright, should have been published in the name of his associates who had done the detailed work-that. his name should have appeared only in the preface, in which he scrupulously mentions the names of Barlow's interns and Rees's laboratory assistant.

Bright's remaining years were given to his consulting practice, to travel, and to his many artistic interests. His practice, which had been slow in coming, grew to be large, perhaps the. largest in Iondon. The honours that he deserved came to him. He was given the Monthyon prize by the Académie des Sciences of Paris. The degree of D.C.L. was conferred on him by Oxford in 1853. As the years passed by he is said to have interrupted his work by long vacations. He was aware for many years before his death that he had a valvular disease of the heart, but he was not interested in his own ills, and the one colleague who is known to have had an opportunity of placing his stethoscope over his sternum was not allowed another chance.

On the night of December 11th, 1858, Bright was seized with melaena associated with great prostration, dyspnoea, and anginoid pains. He failed to rally, and four days later, just after midnight on December 14th, he died.

\section{Some Last Words.}

One cannot look back on this life of unusual achievement without a sense of warm admiration for the man. Happy in his birth and in the surroundings and conditions of his early life, cultivated "by travel and society," an artist, a linguist, a man of scholarly tastes, Bright made full use of his opportunities. Modest, simple, highminded, mellowed by the broadening and softening influences of the experience of a practising physician, Bright appears to have been in the true sense of the word a gentleman, possessed of the $\mu \epsilon \gamma a \lambda \circ \psi v x i a$ of Aristotle, one who moved among men, high and low, with courtesy and sympathy and charity. His equanimity, the sober restraint of his language, his studied avoidance of intemperate or provocative words or acts, excite one's admiration. He seems to have had a rather unusually winning simplicity and purity of character to which his obituary notices bore touching testimony.

$\mathrm{He}$ was a great observer. He was not given to hasty speculation. His mind seemed never to wander from nor to anticipate the phenomena on which his attention was fixed: He examined that which was before him with an objectivity which amounted almost to genius. That which he observed he saw, he remembered, he appreciated; often he recorded. To him who knows how to observe, who has that which we call " insight," to him truth reveals much that she hides from thio many.

A disinterested lover of truth, Bright appears to have been quite oblivious of questions of priority or of personal fame; going out of his way to give credit to his colleagues and to his associates for work done at his suggestion and under his direction. He lost nothing by his generosity. For generosity fame has a sharp and comprehending eye.

One may easily fancy that the reputation which he finally gained as a consultant was justified.

We have gone a long way since the days of Bright. The great advances in the natural sciences and their increasing application to the problems of medicine have revealed to us many secrets of physiology and pathology, and have immensely broadened our knowledge of the causes and nature of disease and of the means by which it may be avoided, recognized, arrested, or healed. A new and scientific therapy based on a broader conception of the functions of the human body, and on the application of sound biological, physical, and chemical principles, is full of promise for the future. Tho simple basic methods of physical diagnosis of the day of Laennec and Bright have been greatly augmented. The little clinical laboratory, the child of his fertile mind-with what wonder and delight would Bright have contemplated its offspring to-day!

Science has contributed much to medicine. But after all how far we are from the day when medicine may be practised by rule of thumb! Science has added greatly to our knowledge of pathology, to the art of diagnosis and of therapy. New and fascinating opportunities for research tempt the student at every turn. The increase of our knowledge and of our technical skill has brought it about that men may devote a whole career to the practice of specialties of surprisingly limited boundaries, specialties which have given rise to a terminology bordering sometimes on the ludicrous. The other day I heard a good fellow solemnly descanting on "the science of sinuology" -the "science," if you will; of the accessory sinuses of the nose! The problems and procedures which a physician must consider to-day when consulted by a patient are far more complicated than they wero in Bright's time. But all this new and precious technique supplements, it does not supplant, the fundamental procedures of observation and physical examination of which Laennec and Bright made use. And we must not forget that a thorough training in the fundamental art of physical exploration is as vital as ever, that the necessary period of experience spent at the bedside of the patient has not been shortened by a day. Familiarity with the symptoms of disease, an ability to recognize and interpret these symptoms-which may be obtained only by experience-are among the first requisites for him who would be a competent physician. No amount of learning can supply this familiarity, this ability. The intelligent interpretation of symptoms is the first-step. He who has not seen the development and progress of disease, he who has not followed the affected subject to his recovery or to his death; he who has not seen his diagnosis confirmed again and again after death, will never attain this familiarity; he will be unfit to practise; much less to teach the art of medicine. The art of diagnosis may not be acquired by the contemplation of radiograms, by the perusal of reports of studies of tissues, body fluids, secreta and excreta, or by the critical consideration of data accumulated by others. As Sergent has well said, one sense may not be substituted for another; the senses are complementary; he who neglects one at the expense of another narrows his horizon.

Laennec and Bright worked with simple tools. Medicine would be poor had we to-day no more. But they worked passing well. They laid foundations on which much has been built; the foundations that they laid were sound.

Between the histories of these two men the contrasts are great. In one respect their lives were similar. Each had a good general and classical education; both were men of wide interests. This is generally true of the greatest figures in medicine. Bright showed early an instinctive interest in the works of Nature, in geology, in botany, in zoology. His was the eye of the naturalist. To most men-indeed to every man with scholarly tastes - life would be unendurable did it not hold for him some engrossing task to accomplish which he is striving in the midst of the routine of existence, some problem he seeks to solve, some investigation he is endeavouring to carry out. With many a man life slips by, and, in the end, it may seem to have been a vain effort, but after all it was that effort, that hope, that carried him on, that brought out tho best that was in him.

Without this spirit of inquiry no one can go far. Spurred by it, the superior man may find the school of practice less alluring perhaps at the outset than the opportunity to devote himself uninterruptedly to the study of some concrete scientific problem; but he will find it no less broadening and no less repaying in the end, and quite 
as full to-day as it was in the days of Laennec and Bright of opportunities for enduring contributions to science and to humanity.

This spirit Bright carried with him throughout his career. He could not have been called a brilliant man. He made at first no great impression on those about him. But brilliancy is often ephemeral; very often brilliancy spells instability. Bright showed a steadfistness of purpose and an equanimity that are rarer and more precious than mere brilliancy. He was a simple, straightforward, kindly man, who met life with charity and tolerance and serenity; a conscientious, painstaking physician; a patient, careful, modest, scrupulous, time-taking observer. He berame a wise and a learned man, and the fruits of his labours assure him a well merited and honourable immortality.

Bright was buried in Kensal Green. There is a tablet dedicated to his memory in St. James's Church in Piccadilly. The inscription ends with these words:

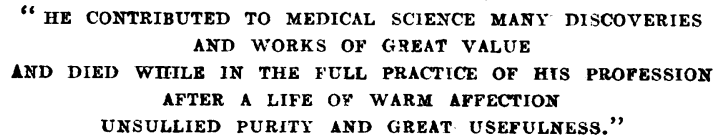

" HE CONTRIBUTED TO MEDICAL SCIENCE MANY DISCOVERIES AND WORKS OF GREAT VALUE

AND DIED WITLE IN THE FULL PRACTICE OF hIS PROFESSION AFTER A LIFE OF WARM AFFECTION

UNSULLIED PURITY AND GREAT USEFULNESS."

\section{An Addrems}

ON THE

\section{CLINICAL AND THERAPEUTICAL ASPECTS OF INFLUENZA-FROM 1889 T0 1927: THE VALUE OF SALICIN IN TREATMENT.*}

\section{E. B. TURNER, F.R.C.S. LONDON.}

The first cases of influenza began to appear in the United Kingdom, after many years of inmunity, in 1889. The last extensive outbreaks had been in the vears 1827 and 1841. In 1837 that great physician and scholar Sir Thomas Watson, writing on the subject of this disease, saw far into the future when he surmised that it might be caused by what he described as a " portable germ." In 1841 there was a very severe epidemic, and during the fifties and sixties of the last century the term "influenza" was applied to almost every case of catarrh with ferer. In 1889 the disease gradually came westward from China, Russia, and other Eastern countries. By some persons it was supposed that the terrible floods in China of that year, when over two hundred thousand people were drowned, may have had something to do with its origin.

In England we heard of influenza, but until the autumn of 1889 no cases came under observation, although it was rampant in France and other European countries. In November of that year I saw my first case-a young man who had come straight from Marseilles. In those days Marseilles was looked upon as the home and place of origin of enteric, typhus, and "other ill defined ferers"; and when I saw him his symptoms simulated those of enteric fever in the early stages, the only trpical one missing being the characteristic rash. I treated him as if he had enteric, more especially as he came from Marseilles, and was much surprised when the whole illness cleared up about the tenth day. I saw many such cases afterwards and was able to recognize them as influenza.

In this first epidemic the prominent symptoms were: pain, especially referred to the back of the eyes, the limbs, and tho back; there was a "foxr" appearance of the eyes, and the tongue, thengh not very coated, had somewhat the appearance of a boiled fig, and there ras a curious sort of "tang" when you touched the skin, which was almost unmistakabje. The temperature and pulse raried in each particular case, but neither ran cxreedingly high. Some cases were of a gastric type, accompanied with vomiting. Complications which affected the patients in this outbreak of influenza were principally of a neurotic character, affecting the nervous

* Presidiential address to the Metropolitan Counties Branch, British Medical Association. system in various ways. - In other cases bronchitis and bronchopneumonia did most mischief. After convalescence there were many sequelae, chiefly neuroses of various kinds, which sometimes lasted for a good many months, in addition to which frequently some mischief, which may have been latent for a considerable time, took on renewed activity.

The epidemic recurred in 1880 , and in each year up till 1895 , in which year the last cases I saw came straight from Paris. From that year onwards the attacks were sporadic, the true cases of influenza being in the minority, while almost every attack of catarrh with fever was, cither by the medical attendant or the patient himself, styled " influenza" - a blessed word like Mesopotamia-it covered a multitude of ills. This state of affairs continued, the true cases occurring in rarying numbers in each year, and the cases which accompanied them and which $I$ have ventured to describe as "pseudo-influenza" being fairly numerous. In 1900 the epidemic was exceedingly widespread, the cases being very numerous, but not of a particularly severe type. In these early epidemics, bacteriology being in its infancy, we have no records of any particular organism being concerned in the production of the disease.

In July, 1918, there was a fairly severe epidemic of true influenza, in character very like those of 1889 and 1890 , but of a more severe type. In all probability a different microbic infection was responsible for it. The complications which were then noticed were bronchitis and bronchopneumonia rather than those affecting the nervous system as in the previous epidemics.

This outbreak subsided, but in the following Novembor there was practically a pandemic of extremely severe it:fluenza. Bacteriological investigation then showed that there was a quadruple infection, and the symptoms and the results were very grave and serious. The principal complication was pneumonia, with hacmorrhage, and fatal cases were exceedingly numerous. In some persons the gastric type predominated, with a great deal of vomiting and stomach disturbance.

In 1919 there was another epidemir, very much like that of November, 1918. In both these epidemics varions sequelae were obsecred, principally affecting the respiratory srstem and in a lesser degree the brain and nervous system. From 1919 to 1921 the incidence of the disease was again sporadic, cases appearing in the winter and spring and the number rapidly decreasing in the summer. In 1921 and 1822 there were also fairly extensive epidemics, milder in character, being more like those of 1889 and 1880, one of the principal complications on these oceasions being affections of the throat and tonsils, complicated also with bronchitis and bronchopneumonia. In 1923, and each year till 1927, also there were epidemics of the disease in winter and spring.

\section{Tireatment}

In 1899 and the carly part of 1890 the cases which came urider miv observation were treated on the then accepted lines-by quinine, salines, ammoniated tincture of quinine, and manr other drugs and methods, none of which had much effect in checking the progress or alleviating the symptoms of the disease. Out of some 115 cases which I then saw I had about the usual arerage of bronchitis and pneumonia as complications, the actual number being 21 .

In 1877 and 1878, on the first introduction of these drugs to Fngland, I had assisted in many of the experiments made with salicin and the salicylates in the treatment of rheumatism, gout, malaria, and other diseases, and had learned at that time that to ensure any pronounced effect from these drugs large doses were necessary. Many authorities, when influenza first appeared, considered it, in those pre-bacteriological days, to be allied to dongue fever, and it appeared to me that perhaps very large doses of salicin might have the same beneficial effect in its treatment.

Farly in 1890 I happened to contract the illness, and $I$ at once tilied this treatment on myself. I took 40 grains of salicin in one dose, and continued for twelve hours, taking 20 grains every hour. Salicin is eliminated from the system with extreme rapidity, and to keep a person thoroughly under its influence it is necessary to give large and rapidly repeated doses. At the end of twelve hours 